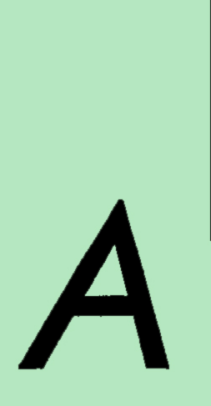

Volume 19, No. 2

ISSN 0515-0361

Volume 19, No. 2
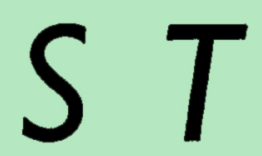

I N
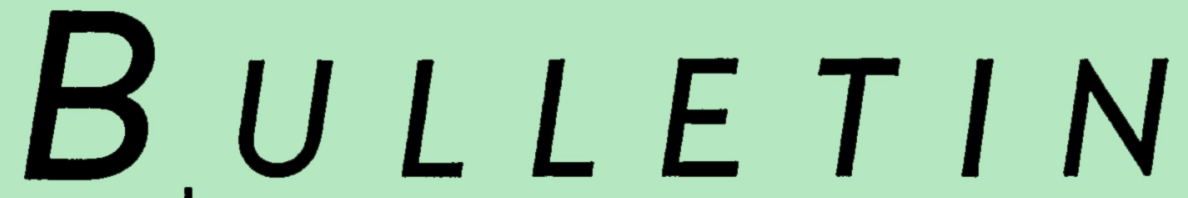

A Journal of the International Actuarial Association

EDITORS:

Hans Bühlmann Switzerland

D. Harry Reid United Kingdom

Co-Editors :

Alois Gisler Switzerland

David Wilkie United Kingdom

\section{EDITORIAL BOARD :}

Björn Ajne Sweden

Marc Goovaerts Belgium

Jacques Janssen Belgium

William S. Jewell USA

Jean Lemaire USA

Walther Neuhaus

Norway

Jukka Rantala Finland

Axel Reich Germany
Contents

\section{EDITORIAL AND ANNOUNCEMENTS}

Editorial

Obituary on Jean Haezendonck

\section{ARTICLES}

\section{J. DhaEne}

Stochastic Interest Rates and Autoregressive

Integrated Moving Average Processes

E. ArJas

The Claims Reserving Problem in Non-Life Insurance:

Some Structural Ideas

J. RANTALA

On Experience Rating and Optimal Reinsurance

E.S.W. SHIU

The Probability of Eventual Ruin in the Compound

Binomial Model

C. M. RAMSAY

On an Integral Equation for Discounted Compound

- Annuity Distributions

\section{WORKSHOP}

G. Dionne, Ch. Vanasse

A Generalization of Automobile Insurance

Rating Models: the Negative Binomial

Distribution with a Regression Component

W. Neuhaus

Mutual Reinsurance and Homogeneous Linear Estimation 213

Actuarial Vacancy 


\section{EDITORIAL POLICY}

ASTIN BULLETIN started in 1958 as a journal providing an outlet for actuarial studies in non-life insurance. Since then a well-established non-life methodology has resulted, which is also applicable to other fields of insurance. For that reason ASTIN BULLETIN will publish papers written from any quantitative point of view-whether actuarial, econometric, engineering, mathematical, statistical, etc. - attacking theoretical and applied problems in any field faced with elements of insurance and risk.

ASTIN BULLETIN appears twice a year, each issue consisting of about 80 pages.

Details concerning submission of manuscripts are given on the inside back cover.

\section{MEMBERSHIP}

ASTIN is a section of the International Actuarial Association (IAA). Membership is open automatically to all IAA members and under certain conditions to non-members also. Applications for membership can be made through the National Correspondent or, in the case of countries not represented by a national correspondent, through a member of the Committee of ASTIN.

Members receive ASTIN BULLETIN free of charge.

\section{SUBSCRIPTION AND BACK ISSUES}

ASTIN BULLETIN is published and printed for ASTIN by Ceuterick s.a., Brusselsestraat 153, B-3000 Leuven, Belgium.

All queries and communications concerning subscriptions, including claims and address changes, and concerning back issues should be sent to Ceuterick.

The current subscription or back issue price per volume of 2 issues including postage is BEF 1700 .

\section{INDEX TO VOLUMES 1-13}

The Cumulative Index to Volumes 1-13 is also published for ASTIN by Ceuterick at the above address and is available for the price of BEF 340 . 